\title{
Images of Women in Abhijnanashakuntalam as Role Model for Women Empowerment
}

\author{
Shyama Khanal \\ Lecturer, English Department \\ NSU, Janata Campus, Bijauri, Dang, Nepal \\ Email: Shyama.khanal@nsu.edu.np
}

(Abstract: This Paper aims to oversee the forms and image of women in the play Abhijnanashakuntalam written by Kalidasa; a great poet in Sanskrit literature. It is found that most of his works represent two different aspects of woman, one in the form of the poetic and artistic depiction of woman and the other in the form of her status in the prevailing society. The women were able to inspire action and hero's aspirations with her own nobility and deep human affection which is the typical image for female character and an endless source of inspiration for contemporary art and literature. Hence, the portrayal of women is with the outer and inner beauty in relation to social issues like religion, caste, marriage, sacrifice etc.)

Keywords: Role model, women empowerment, sub-human beings, pilgrimage, hermitage.

\section{Introduction}

Sanskrit epic literature contains comparatively large numbers of descriptions of heroes and heroines who participate in the main plot of the epics, or in the tales which form independent sub-stories and episodes (Milewska, 2015). Kalidasa probably lived in the fifth century of the Christian era; Kalidasa and his contemporaries lived while Rome was tottering under barbarian assault. Hindus have ever regarded him as the greatest poet of Sanskrit literature. Kalidasa left seven works: three dramas, two epics, one elegiac poem, and one descriptive poem. Among them Abhijnanashakuntalam is the masterpiece in Sanskrit literature.

The Portrayal of Woman is widely presented throughout the epics, poems and dramas in Sanskrit literature. Kalidasa wrote his works to satisfy the interest of specific audiences and readers which points to the absence of innocence in the narration. It is perhaps an inevitable consequence of Kalidasa's subject that his women characters 
appeal more strongly to a modern reader than his men characters. The general characteristics of the women in the play were their compassion and generosity, their persistence and patience spirit, their love, faithful loyalty and the desire for happiness which are considered as "the golden rule". Generally, all woman characters appear at the marriageable age as wives or loved ones. But the commonality in most of the female characters in the works of Kalidasa is the benevolence and mercifulness, the persistence and patience, the desire for happy love. Although women in the contemporary time did not play an important role, were not respected in the family and in society, they also had a spiritual support and foundation for hero's strength in particular and community strength in general. The women were able to inspire action and hero's aspirations with her own nobility and deep human affection. The woman with perfect and flawless beauty is not only beautiful in appearance, but also beautiful inside with virtuous personalities. In Abhijnanasakuntalam also we observe active and independent role of woman. The personality of Sakuntala is shown as a simple hermit girl who strove hard to attain her goal. This play consists of Seven Acts, based on the love story of king Dushyanta and the maiden Sakuntala, as given in the ancient Indian epic, the Mahabharata.

This paper has attempted to interpret the roles and images of women in the play, Abhijnanashakuntalam. It has also analyzed the social norms of the contemporary Nepalese society that dominate women and the role of female character as the reformer through struggle, patience and devotion towards their duties. It has also overseen the way Kalidasa portrayed the forms and images of his female character in this play.

\section{Methodology}

This study basically follows the textual interpretation, literary reviews, and theological aspects being based on textual analysis and discourse analysis.

\section{Theoretical Perspective of Feminism}

Feminism is a complex notion that has vast differences in meaning and connotation for people spanning generations, ethnic identities, sexual orientations, social classes, nationality, and myriad identities. Feminism is not a static notion; rather it evolves with us throughout our lives and is shaped by the various lenses we use to view the world at large and, most importantly, ourselves (Hooks, 2000).

Feminist literary criticism is the critical analysis of literary works based on the 
feminist perspective. In particular, feminist literary critics tend to reject the patriarchal norms of literature "that privileges masculine ways of thinking/points of view and marginalizes women politically, economically and psychologically," according to Paul Ady, associate professor of English at Assumption College in Worcester, Massachusetts. Instead, feminist critics approach literature in a way that empowers the female point-of-view instead, typically rejecting the patriarchal language that has dominated literature. (Award, 2017)

Modern feminist literary criticism had its roots in the post- World War II feminist movement that spilled over into the intellectual circles of America's colleges and universities. The true origins of movement can be traced as far back as the late $18^{\text {th }}$ century with Mary Wollstonecraft's "A Vindication of the Rights of Women" (1792). Other writers such as John Stuart Mill, Margaret Fuller and Simone De Beauvoir followed suit from the mid- $19^{\text {th }}$ century to the mid- $20^{\text {th }}$ century.

\section{Discussion and Analysis of the play}

Kalidasa's play Abhijnanashakuntalam has been seen through different lenses in the following chapters.

\subsection{Different Characters in Abhijanasakuntalam}

Sir William Jones' Works of Kalidas, Translated from Original Sanskrit into English, (1901) is the basic text for the review of the drama.

Abijnashakuntalam, a fine play in seven acts is the most famous among the works of Kalidasa and the best among the poetic works. This is based on the love story of king Dusyanta and Shakuntala, parents of Bharata, the famous and founder father of Bharata dynasty. The first meeting of the king with Shakuntala in the hermitage of Kanva, who was on a pilgrimage to avoid the misfortune in the life of Shakuntala, is dealt with in the first act. In the second act the king pretended to protect the hermitage, though demanded by his mother, and sent vidusaka to the capital. In the third, Shakuntala conveyed her love through a letter and got married under the gandharva system. Dusyanta returned to the capital promising to take her within three days. Durvasa cursed Shakuntala for not receiving him, as she immersed in the thought of Dusyanta. Her female maids managed the situation and secured concessions. Act IV describes the departure of Shakuntala to the capital accompanied by ascetics and loss of token rings. Act V details Dusyanta's refusal, her rescue by mother Menaka etc. Act V1 is the story of a childless fisherman, who brought the ring by which Dusyanta 
could remember Shakuntala and regretted it. In act VII, Dusyanta accompanied Matali to fight against a demon on Indra's demand. Visit of Dusyanta to the hermitage of sage Marica, on his return journey is detailed in the last chapter. There he met his son, Sarvadamana, and Shakuntala and got united with the blessing of Marica and Aditi.

Kalidasa recreates Shakuntala in the play as an obedient, virtuous woman who is steadfast in her love (unlike apsaras) even after being abandoned. Thus, Kalidasa creates an image of the dutiful wife, who even in the face of injustice does not abandon her responsibilities.

Through Shakuntala we see Kalidasa's attempt at rewriting apsara femininity in creating a compliant, dutiful, pativrata wife who would serve as an example of ideal womanhood. Shakuntala is purged of her deviant femininity and can therefore be celebrated in the play as the heroine.

The play also offers us a look into the expected female behavior in the Vedic period through the repeated instructions on how to be an ideal wife which we see in Kanva's advice in Act IV.

Kanva: My beloved child: Be held in high esteem by your lord as Sarmistta was by Yayati; as she bore Puru, may you too bear a son to whom the whole world will bow. My child, you are now leaving for your husband's home; when you enter it: Serve your elders with diligence; be a friend to your co-wives; even if wronged by your husband do not cross him through anger; (p. 227)

The matron Gautami also opines her relating with the view point of Kanva implying that was how young girls were trained to behave in their marital homes. "Gautami: The best advice for a young bride. (To Shakuntala) Dear daughter, keep these precepts always in mine (p. 227)". Gautami and the other female ascetics reiterate this advice as well. Even as her hermit companions abandon Shakuntala, these ascetics do so by telling her to do her duty as a wife and stay with her husband, even though it is clearly visible that he does not want her.

Sarngarava: If you are what the King says you are, what will your father have to do with you - a stain on his family? But, as you know your own conduct to be pure, even servitude in your husband's house will be welcome to you. Stay here; we are leaving. (p. 241)

These wifely duties are referenced in the final act where Marica is said to be 
busy preaching to Aditi and the wives of other sages on the conduct of a virtuous wife. So we can see a running preoccupation with women's behavior and how to create ideal women in the play. These dictates essentially tell women to obey their husbands and to bear them sons to carry forward the lineage, outlining their duties as mothers and wives. Nowhere do these dictates incorporate women's feelings or their personal desires. In fact, Kanva in Act IV considers women as others' wealth, to be taken care of till they are given away and is relieved that he has finally given Shakuntala away to Dusyanta.

\subsection{Shakuntala as Role Model for Women Empowerment}

The term empowerment is widely used in the context of women development. It is a state of mind and attitude of an individual. Kalidasa's Shakuntala, Urvasi, Uma and Sita are all empowered women in this sense. They exhibited great ability to overcome restrictions and constraints imposed by the social customs, beliefs and practices. Kalidasa considerd women as the power incarnated; the strength that makes man act in the right way and direction. Dharini rules with love and justice. She is the savior of the king. Urvasi is well educated and cultured lady. Shakuntala is not the suffering victim rather she overcome challenging circumstances empowered with inner strength. In the patiently suffering Shakuntala is an empowered woman who is proud of her self-identity and patiently waiting for a recognition of her virtues. Her empowerment lies in facing and overcoming oppressive environment. Prof. Hari Dutt Sharma traces the strength and empowerment needed for the modern- day women, in Kalidasa's Heroines. He has identified Sita, Parvati and Shakuntala with their courage, confident and stability as role models for the present generation. Kalidasa has achieved great success in the presentation of female characters, they experience more troubles and undergo greater sufferings. They are alive to the tradition that love is for order and harmony.

\subsection{Sakuntala, its Inner Meaning}

As per etymology, the word Shakuntala is formed with the union of two- i.e. Shakunta; the bird and la; nourishment. The whole meaning of it is the child who is nourished by the birds. This is the literal meaning of the title, but the inner meaning is quite different. It seems as if the poet Kalidasa wants to indicate his views about beauty. "The appearance of which gives new feelings at every moment is the true definition of beauty." (Shastri, 2015. p. 43) 
So, as the multi- coloured birds attract one's mind towards them, accordingly, the skillfully created Shakuntala's beauty, simplicity, mildness, honeyed tongue etc. qualities make her an unparalleled beauty queen. So, the unique beauty is another meaning of the play. Dushyanta beautifies her with the words:

Dusyanta: She seems a flower whose fragrance none has tasted, A gem uncut by a workman's tool, A branch no desecrating hands have wasted, Fresh honey, beautifully cool. No man on earth deserves to taste her beauty, her blameless loveliness, and worth, unless he has fulfilled man's perfect duty-And is there such a one on earth? (II.I 21)

The above lines present the dialogue of Dusyanta who praises Shakuntala regarding her beauty both inwardly and outwardly. Shakuntala, the heroine of the play, is the most beautiful, virtuous, chaste and simple. As she grows in the hermitage, she loves every natural thing. Her sympathetic attitude towards the sub- human beings comes forth and sets an example of her divine greatness. Deeply drowned in the memories of her husband, she forgets to welcome sage Durvasa and appease him, and for the negligence she was cursed by the sage which led her to misery and shameful condition.

In this play nature plays a vital role. In the lap of nature the entire story takes place. Kalidas, a devotee of nature, has beautifully described the charms of nature. In fact, compounding of internal and external nature is the specialty of the art of Kalidas. In short, Abhigyan Shakuntalam is an excellent presentation of human love and natural love.

\subsection{Social Values of Women in the Play}

Social values form an important part of the culture of the society. They provide the guidelines for social conduct. Values such as fundamental rights, patriotism, respect for human dignity, rationality, sacrifice, individuality, equality etc. guide our behavior in many ways. Values are the criteria people use in assessing their daily lives; arrange their priorities and choose between alternative courses of action. Social values like emotions, behavior, attitude, feelings and experiences, mental states, the degree of patience, the quality of forgiveness, reaction to social situations, modesty and decency etc. of women are reflected in the play. Abhijnanasakuntalam. Various social values of women can be seen in each act of the play which are more beneficial to human society and the present day world on the one hand and on the other hand it presents 
the oppression of social norms and values only towards the side of females.

A man of a higher class was allowed to marry, besides a girl of his own class, a girl of lower class. In the case of girls, they are not freely or independently allowed to do anything as she wishes. There are certain social, religious taboos which operate as social sanctions. To abide entirely by the wishes of her husband and to be devoted to his well-being alone, is considered to be the highest duty of a Hindu woman. There is an abiding faith in the institution of marriage as not just a private affair but as a sacrament, otherwise they would be punished in the name of curse or fate. It shows that there was no more respected place for women at the time of Kalidasa, only they were used as imagery of beauty and romance. Women are strictly restricted in every sphere to breathe an independent life. They are recognized as the oppressed class of the society and merely a puppet in the hands of male dominating society.

\subsection{Significance of the Theme in Relation to Our Society}

The memorable women characters Kalidasa has created are true representations of different facets of Nepalese womanhood. A closer look at important women characters in the plays and poems of Kalidas reveals qualities which go beyond conventional beauty and traditional feminine passivity. Kalidasa presents women from all strata of society- queens, concubines, maids-in-waiting, and ascetics. Kalidasa's heroines, mother-figures and supporting minor characters are in their own capacity embodiments of women's empowerment.

It cannot be ignored that a wide range of interesting academic literature has been published in relation to women images in the ancient Sanskrit Literatures and women characters in the works of Kalidasa as well. However, what is tried to be done is, build upon such works by investigating the topic through an alternative analytical lens; one in the form of the poetic and artistic depiction of woman and the other in the form of her status in the prevailing society. How was the patriarchal domination in the works of Kalidasa, have the women characters realized the domination, did they give up their hopes and how they struggled to achieve their right. Interpretation of any literary works depends on the present socio-cultural as well as socio-political situation. For example, interpretation of the king in Nepal differs before the declaration of a republic country and after the declaration. That's why, the evolution of language necessitates bringing out an interpretative quality. Not only it fills the gap in academic knowledge, but also addresses the socio-cultural issues of women outside of academia. 
Kalidasa has been able to balance the romance and the bitter fact of his characters on one side and the high cultural aspect of our civilization especially in the context of women on the other side. He has achieved greater success in presenting the women characters in his foreside. He has depicted women as beautiful, clever, virtuous, amiable and self- sacrificing. They are faithful wives and affectionate mothers of illustrious sons. Free from conventionalism, they are true, tender hearted, brave and devoted wives and affectionate mothers. Free from conventionalism, they are true, tender hearted, brave and devoted wives. They have wisdom and understanding, firm in determination, they follow the right path and sacrifice pleasures for the sake of their husbands. They serve their husbands as homemakers and always accompany them in the performance of duties. They are the root of social welfare and religious activities.

Kalidasa has presented the theme connected with cultural and social norms being based on the high ideals of Hindu religion. He has emphasized that love cannot be put before our duties. If there are lapses on our duty front we have to repay it adversely. This has been the case with Shakuntala when she had unknowingly lapsed in performing her duties by not welcoming rishi Durvasa. Kalidasa's motive was to depict that neglect of duty is punishable. However, Shakuntala is an empowered woman with her positive self-image and self-confidence and is able to keep up her dignity in the oppressive environment.

In Abhijnanashakuntalam, Kalidasa has used his pen to sing the praises of the pure, truthful love, the innocent soul and the legitimate aspirations of humans in the life that is love and criticized the teachings that stifled the fluttering heart of humans. In his work, Kalidasa let his characters act and express their personalities in these relationships to talk about the issues of love and caste. This has made the success of the play Shakuntalam, and has raised the thought of Kalidasa over his contemporaries and authors of later centuries. Kalidasa used the beauty of nature to compare with the beauty of humans, to give the background for the girl's beauty.

\section{Conclusion}

The major concern of this study was to navigate the forms and images of women in the play, Abhijnanashakuntalam. The researcher closely analyzed and studied the status of women in the play of Kalidasa where they were depicted as the role model for women empowerment, despite their suffering and negligence in the patriarchal society. One Pertinent quality of the women which assigns them the status to act as role 
models to the contemporary global women is their underlying strength as evidenced in their capacity to make reasonably sound decisions. Shakuntala's quiet suffering and her refusal to beg for kindness from the king which lends her an aura of victorious strength when she appears in the last act. She is the ideal role-model for the girls of that section of our society. Nepalese woman, still today experience subordination daily in the form of discrimination, disregard, insult, control, exploitation, oppression, violence due to the patriarchal ideology which have spread the notion of male superiority through the religious stories of Ram-Sita, Shiva-Parvati that gives a lesson that a woman's heaven is in her husband's feet (Khanal, S. 2072). Kalidasa wrote with a purpose that every character he portrayed and every incident he represented had a message to convey the main purpose being the woman what she was and to remind the man that he should not trespass on the rights of his counterpart. Kalidasa's women characters are empowered a lot and deserve respect, love, reverence and wonder.

In Abhijnanashakuntalam, Kalidasa has used his pen to sing the praises of the pure, truthful love, the innocent soul and the legitimate aspirations of humans in the life that is love and criticized the teachings that stifled the fluttering heart of humans. In his work, Kalidasa let his characters act and express their personalities in these relationships to talk about the issues of love and caste. This has made the success of the play Shakuntalam, and has raised the thought of Kalidasa over his contemporaries and authors of later centuries. Kalidasa used the beauty of nature to compare with the beauty of humans, to give the background for the girl's beauty. Empowerment is a term widely used in the context of women's development.

Kalidasa has presented the theme connected with cultural and social norms being based on the high ideals of Hindu religion. He has emphasized that love cannot be put before our duties. If there are lapses on our duty front we have to repay it adversely. This has been the case with Shakuntala when she had unknowingly lapsed in performing her duties by not welcoming rishi Durvasa. Kalidasa's motive was to depict that neglect of duty is punishable. However, Shakuntala is an empowered woman with her positive self-image and self-confidence and is able to keep up her dignity in the oppressive environment.

\section{Acknowledgements}

I am indebted to the authors whose works have been sighted in this article. I am also grateful for the insightful comments offered by the anonymous peer reviewers. In 
addition, I would like to thank the editorial team for their support throughout.

\section{References:}

Adward, A. (2017). Anil Awad's Quest For Literature: Feminist Approach to Literary Criticism. https:// Anilawards. Blogspot.com

Hooks, B. (2000). Feminism Is for Everybody: Passionate politics. Cambridge, South End Press.

Kalidasa Shakuntala. (1999). Translated by Arthur Ryder, Parentheses Publication, www.yorku.ca/inpar/shakuntala_ryder.pdf.

Khanal, S. (2072). Women Issues: How long to neglect? Haimaprabha- Vol 14, 2072. A Peer Reviewed Journal of Nepal Sanskrit University, Janata Vidhyapeeth, Bijauri Dang

Mason, D. (2007). Shakuntala: A Play by Kalidasa (review). Asian Theatre Journal, 24(2), 536-538. doi:10.1353/atj.2007.0038

Nayek, D. (2020). From Shakuntala to Sanitary Panels: Women in Indian Graphic Narratives. Feminist Encounters: A Journal of Critical Studies in Culture and Politics, 4(1), 15. https://doi.org/10.20897/femenc/7919

Panday, S.D. (1996). A critical appraisal of Kalidasa's Abhijnanasakuntalam in the light of the rasa theory. Submitted in partial fulfilment of the requirements for the degree of Doctor Litterarum in the Department of Indian Languages (Sanskrit) in the Faculty of Arts at the University of Durban Westville. Accessed from https://researchspace.ukzn. ac.za/handle/10413/8678 accessed on 5 January 2021.

Rajan. C. (1990). The Loom of Time: A Selected plays of Kaladasa. New Delhi. Penguin Books, India.

Shastri, B.P. (2015). Abhijyanasakuntalam. New Delhi. Chaukhamba Publishing House.

Singh, J. (2013). The Female Players in the selected plays of Kalidasa https://www. researchgate.net/publication/236735517

William, J. (1901). 'Works of Kalidasa'. H.C. Dass Elysium Press. Nayan Chand Dutt street. 